\title{
Effect of rate of substitution of processed, urea-treated whole- crop wheat for grass silage on the intake, milk production and diet digestibility in dairy cows and ruminal metabolism in vitro
}

\author{
L. A. Sinclair ${ }^{1 \dagger}$, A. J. Bond ${ }^{1}$, J. A. Huntington ${ }^{1}$ and R. J. Readman ${ }^{2}$ \\ ${ }^{1}$ ASRC, Harper Adams University College, Edgmond, Newport, Shropshire TF10 8NB, UK; ${ }^{2}$ CERC, Harper Adams University College, Edgmond, Newport, Shropshire \\ TF10 8NB, UK
}

(Received 10 August 2006; Accepted 29 November 2006)

\begin{abstract}
The effect of rate of substitution of processed, urea-treated whole-crop wheat (pWCW) for grass silage on intake, performance and whole-tract digestibility was evaluated using 44 dairy cows. Cows received $10.5 \mathrm{~kg}$ of concentrates per day and one of the following forage mixtures (dry matter (DM) basis): grass silage alone (W-0); 0.75 grass silage, 0.25 pWCW (W-25); 0.5 grass silage, $0.5 \mathrm{pWCW}(\mathrm{W}-50)$ or 0.25 grass silage, $0.75 \mathrm{pWCW}(\mathrm{W}-75)$. Forage DM intake increased linearly with inclusion rate of pWCW from $9.7 \mathrm{~kg}$ DM per day in cows fed $W-0$ to $14.6 \mathrm{~kg}$ DM per day in $W-75$. By contrast, milk and protein yield (kg/day) were higher $(\mathrm{P}<0.05)$ in cows receiving $W-25$ compared with $W-0$, but there was no effect $(\mathrm{P}>0.05)$ of treatment on fat yield $(\mathrm{kg} /$ day). From week 11 of the experiment onwards, body condition score increased with rate of inclusion of pWCW $(\mathrm{P}<0.05)$. Whole-tract apparent digestibility of organic matter (OM) and fibre $(\mathrm{kg} / \mathrm{kg})$, decreased linearly with rate of inclusion of pWCW. Assuming a constant digestibility of starch in the other diet components, the apparent digestibility of starch in pWCW was $0.95 \mathrm{~kg} / \mathrm{kg}$ and was not affected by rate of inclusion $(\mathrm{P}>0.05$ ). Four continuous culture vessels were used to determine the effect of rate of inclusion of pWCW on ruminal metabolism in four periods, each of $14 d$ duration with sampling conducted on days 9 to 14. Vessel ammonia concentration increased linearly $(\mathrm{P}<0.05)$ with rate of inclusion of $\mathrm{pWCW}$ whilst mean $\mathrm{pH}$ tended $(\mathrm{P}=0.06)$ to decrease. The ratio of acetate to propionate increased from 2.5 in vessels receiving $W-0$ to 3.2 in those receiving $\mathrm{W}-75(\mathrm{P}<0.001)$. There was no effect $(\mathrm{P}>0.05)$ of treatment on digestibility $(\mathrm{g} / \mathrm{g})$ of $\mathrm{OM}$, fibre or starch or microbial protein flow ( $\mathrm{g} /$ day). It is concluded that forage DM intake increased linearly with rate of inclusion of $\mathrm{pWCW}$, but there was no further improvement in milk yield from inclusion rates above 0.25 of the forage DM, with body condition score increasing instead. Increasing the inclusion rate of pWCW resulted in a more ketogenic volatile fatty acid profile but did not affect the efficiency of microbial protein synthesis when determined in vitro.
\end{abstract}

Keywords: dairy cows, digestibility, in vitro digestion, whole-crop wheat

\section{Introduction}

Whole-crop wheat (WCW) is an alternative forage to grass silage, particularly in temperate grass growing areas where forages such as maize do not grow well. Compared with grass silage, traditional means of preserving whole-crop cereals, either by fermenting at lower dry matter (DM) values $(300$ to $500 \mathrm{~g} / \mathrm{kg}$ ) or urea-treatment at higher DM values $(600$ to $700 \mathrm{~g} / \mathrm{kg}$ ), have resulted in a significant increase in DM intake but had little effect on milk yield (Hameleers, 1998; Sutton et al., 2001; Sinclair et al., 2003). Studies that have compared WCW with good-quality maize silage have reported a lower milk yield (Phipps et al.,

\footnotetext{
${ }^{\dagger} \mathrm{E}$-mail: Isinclair@harper-adams.ac.uk
}

1995). Abdalla et al. (1999) and Sutton et al. (1998) demonstrated that ruminal and whole-tract digestibility of fibre and particularly starch was depressed in cows fed diets containing urea-treated WCW, and suggested that improvement of ruminal starch digestibility may enhance performance.

Recently, a processor that is fitted to the forage harvester has been developed that allows the grains in WCW to be cracked prior to ensiling. Jackson et al. (2004) reported that processing higher DM WCW at harvest and preserving with urea (pWCW) increased forage starch digestibility from 0.80 to $0.97 \mathrm{~kg} / \mathrm{kg}$, and reduced the number of whole grains excreted in the faeces. The cows responded to this greater nutrient availability by decreasing 
forage intake, with little effect on milk yield (Jackson et al., 2004). When compared with maize silage, the inclusion of pWCW resulted in a similar milk and milk component yield (kg/day), although forage DM intake was substantially higher (Sinclair et al., 2005; Murphy et al., 2004).

Inclusion rate of urea-treated WCW has ranged from 0.22 of the forage DM (Hill and Leaver, 1991) to 1.0 (Hill and Leaver, 1999) but there has been no consistent effect on dairy cow performance. Sutton et al. (1998) reported that milk yield tended to be highest when cows were fed unprocessed, urea-treated WCW at 0.67 of the forage DM, and this inclusion rate has been used in the majority of recent experiments that have evaluated pWCW (Jackson et al., 2004; Murphy et al., 2004; Sinclair et al., 2005). One objective of the current experiment was therefore to investigate the effects of rate of inclusion of pWCW on the intake, performance and whole-tract digestibility in dairy cows. An additional objective was to examine the effects of inclusion rate of pWCW on ruminal metabolism because despite the large influence of forage digestion in the rumen on animal performance (Abdalla et al., 1999), few studies have been conducted in this area. The use of continuous culture fermentors to simulate the ruminal environment enables the study of factors that may affect the microbial ecology and digestion of nutrients (Stern et al., 1997) whilst providing a cheaper, more rapid and repeatable alternative to in vivo studies (Owens and Goetsch, 1988).

\section{Material and methods}

The work described in this paper was conducted in accordance with the requirements of the UK Animals (Scientific Procedures) Act 1986 (Her Majesty's Stationery Office, 2000).

\section{Forage production}

A commercial crop of winter wheat (cv. Equinox) was grown using standard agronomic practice on a sandy clay loam soil following a 3-year grass ley. Crop DM was monitored twice weekly from approximately 4 weeks pre-harvest by cutting two adjacent $0.5 \mathrm{~m}$ lengths of row at approximately $15 \mathrm{~cm}$ stubble height at six random positions throughout the field and air drying to constant weight at $105^{\circ} \mathrm{C}$. The crop was harvested on the 4 August 2003 (growth stage (GS) 92; Tottman and Broad, 1987) and cut and processed using a forager fitted with a forage mill as described by Jackson et al. (2004). The forage was ensiled in a concrete walled roofed silage clamp and a urea and urease additive (Volac Home n'Dry, Volac, Royston, UK) added to provide $20 \mathrm{~kg}$ of urea per tonne of forage DM. The clamp was rolled well and sealed using a double layer of plastic sheeting and weighted down with tyres. The grass silage was a first-cut harvested using a self propelled, precision-chop forage harvester (Class Jaguar 800 series, Claas, Bury St Edmonds, UK) on 30 May 2003 from a predominantly perennial ryegrass sward, wilted for $24 \mathrm{~h}$, received no additive and was ensiled in a concrete-walled clamp. The grass silage and pWCW were ensiled for approximately 180 and 110 days respectively prior to feeding.

Immediately prior to harvesting, the wheat crop DM yield was assessed by cutting an area of $0.72 \mathrm{~m}^{2}$ to ground level at 10 random positions within the area to be harvested. The material was separated into ensiled material and residual material remaining in the field after harvest by cutting at $19 \mathrm{~cm}$ above the stem base. Grain yield was determined by cutting ears from the ensiled material and threshing using a single ear thresher (Wintersteiger-AG, Austria), modified to allow quantitative recovery of grain and chaff. Grain was then separated by passing the grain and chaff over a grain cleaner fitted with a 3.5-mm top sieve and a 2-mm bottom sieve. The mean crop height prior to harvest was 68.4 (s.d. 3.9) cm, and the mean stubble height post-harvest 19.0 (s.d. 1.9) cm. Total above ground DM yield was 17.2 t DM per ha and mean crop yield 15.2 t DM per ha, with a grain yield (adjusted to $15 \%$ moisture) of $10.4 \mathrm{t} / \mathrm{ha}$.

\section{Animals and experimental procedure}

Forty-four Holstein-Friesian dairy cows (four prima and 40 multiparous) that were on average 29 (s.d. $+I-5.5$ ) days into lactation were used in a 14-week continuous design. Based on recordings taken when the cows were in week 3 of lactation, animals were blocked according to parity (prima or multi), calving date, milk yield, condition score (Lowman et al., 1976) and live weight and randomly allocated to one of four dietary treatments. Cows were housed in cubicles fitted with rubber mattresses, bedded with chopped paper twice weekly with the loafing area cleaned using automatic scrapers four times daily. All animals had continuous access to water.

The four dietary treatments were formulated according to Agricultural and Food Research Council (AFRC, 1995) and varied in their inclusion rate of grass silage and pWCW (DM basis): grass silage alone (W-0); 0.75 grass silage, $0.25 \mathrm{pWCW}(\mathrm{W}-25) ; 0.5$ grass silage, $0.5 \mathrm{pWCW}$ $(\mathrm{W}-50)$ or 0.25 grass silage, $0.75 \mathrm{pWCW}(\mathrm{W}-75)$. Two forage samples were taken weekly; one was oven dried at $100^{\circ} \mathrm{C}$ to constant weight to maintain the grass silage to pWCW ratio and the remaining sample frozen at $-20^{\circ} \mathrm{C}$ prior to subsequent analysis. All animals received $7.0 \mathrm{~kg} /$ day of a standard dairy concentrate $(\mathrm{g} / \mathrm{kg}$ : 200 wheat, 150 rapeseed meal, 140 dried sugar-beet feed, 140 palm kernel extract, 120 sunflower meal, 100 soya-bean meal, 60 molasses, 42 Megalac $^{\circledR}$ (Volac UK Ltd, Royston, UK), 20 fatty acid distillate, 13.2 limestone, 10 calcined magnesite, 3.8 salt and 1 mineral and vitamin pre-mix (which provided on a total-concentrate basis (mg/kg): $\mathrm{Cu} 40 ; \mathrm{Mn} \mathrm{80;} \mathrm{Zn}$ 120; Co 1; I 6; Se 0.5; retinol 2.4; cholecalciferol 0.05; and alpha-tocopherol acetate 30) in two equal meals through out of parlour feeders. Each cow also received $2 \mathrm{~kg} /$ day of rapeseed meal, $1.5 \mathrm{~kg} /$ day of sugar-beet feed and $0.5 \mathrm{~kg} /$ day of Lactofeed (a lactose containing supplement; Volac 
UK Ltd, Royston, UK), which was mixed with the forage mixture and fed through electronic food bins which measured intake by weigh cells located under the bins and individual collar transponders fitted onto each cow (Insentec, Marknesse, Holland). The forage mixture was fed once daily at approximately $0900 \mathrm{~h}$ at a rate of 1.05 of the calculated intake, with refusals collected twice weekly.

Cows were milked twice daily at approximately 0630 and $1630 \mathrm{~h}$ with yield recorded at each milking and samples taken on a Mon p.m. and Tues a.m. for subsequent analysis. Cows were weighed, condition scored and locomotion scored (Manson and Leaver, 1988) weekly at $1400 \mathrm{~h}$. Blood samples were collected by venipuncture from the coccygeal vein from a subsample of six cows per treatment during weeks $0,3,8$ and 13 of the experiment. The individual blood samples were taken at $1100 \mathrm{~h}$ into two vacutainer tubes containing either potassium oxalate or lithium heparin as anti-coagulants, centrifuged immediately and the plasma stored at $-20^{\circ} \mathrm{C}$ prior to subsequent analysis. Diet apparent digestibility was measured in five cows per treatment when they were in week 10 of the experiment, using acid insoluble ash as an indigestible marker (Van Keulen and Young, 1977). For 7 days approximately $100 \mathrm{~g}$ of faeces were collected at 0900 and $1500 \mathrm{~h}$ from each cow by grab sampling and stored at $-20^{\circ} \mathrm{C}$ prior to subsequent analysis.

In vitro digestibility and metabolism

An in vitro continuous culture system adapted from Hoover et al. (1976) was used. Four double-layered glass in vitro fermentor vessels of $1.18 \mathrm{I}$ volume were maintained at $39^{\circ} \mathrm{C}$ by continuously pumping water from a bath (Ecoline RE106, Lauda, Germany) around the jacket of each vessel. Each vessel had a $20 \mathrm{~mm}$ internal diameter overflow port and artificial saliva (McDougall, 1948), modified to contain $13.8 \mathrm{mg} / \mathrm{l}$ ammonium sulphate and diluted 60:40 with deionized water; Rufener et al., 1963) was infused continuously at the rate of $69 \mathrm{ml} / \mathrm{h}$ via a port in the head plate which also permitted a continuous flow of $\mathrm{CO}_{2}$ and monitoring of vessel temperature. Vessel contents were mixed using a motor controlled stirrer (Crouzet Ltd, Hampshire, UK) attached to the head-plate, with the contents mixed for $5 \mathrm{~min}$ every $0.5 \mathrm{~h}$ at approximately 20 turns per $\min$. Additional agitation was achieved by manually stirring the vessel contents after feeding to ensure feed was absorbed through the raft. Outflow was collected from the overflow port into a container maintained at $3^{\circ} \mathrm{C}$, with contents removed three times daily and stored at $-20^{\circ} \mathrm{C}$.

Four wether sheep fitted with permanent rumen cannulae $(39 \mathrm{~mm})$ that were group housed and bedded on chopped straw were used. The sheep had continuous access to water and were fed a forage mixture consisting of grass silage and pWCW (50:50 DM basis), twice daily at $0800 \mathrm{~h}$ and $1600 \mathrm{~h}$ at 1.1 maintenance energy requirements (AFRC, 1995). The animals were fed the basal diet for 2 weeks prior to the first inoculum collection and were not bedded up 2 days prior to rumen fluid collection.
Rumen fluid was removed by suction $4 \mathrm{~h}$ after the morning feed into pre-heated vacuum flasks under $\mathrm{CO}_{2}$, pooled between sheep and strained through four layers of muslin cloth at $39^{\circ} \mathrm{C}$. The vessels, which were previously flushed with $\mathrm{CO}_{2}$ and filled with $510 \mathrm{ml}$ artificial saliva, were then inoculated with $670 \mathrm{ml}$ of rumen fluid. New rumen fluid was used to charge the vessels at the beginning of each experimental period.

The vessels were fed $30 \mathrm{~g}$ DM per day of one of four dietary treatments in a $4 \times 4$ Latin-square design with each period lasting 14 days. The diets consisted of (g DM per day) 8.25 dairy concentrate, 2.4 rapeseed meal, 1.8 sugar-beet feed, 0.6 Lactofeed (Volac UK Ltd, Royston, UK) and 16.95 forage mix. The forage mix contained (DM basis) either grass silage alone (W-0); 0.75 grass silage, 0.25 WCW (W-25); 0.50 grass silage, 0.50 WCW (W-50) or 0.25 grass silage, 0.75 WCW (W-75). All feed ingredients were freeze-dried and ground through a 3-mm screen and the feed introduced via a $25-\mathrm{mm}$ aperture in the head plate in three equal meals at 0800,1600 and $0000 \mathrm{~h}$.

Days 1 to 8 of each period were used as an adaptation period with sampling occurring on days 9 to 14 . Protozoa were counted on days 1 and 13 by adding $5 \mathrm{ml}$ of vessel outflow to $4 \mathrm{~g} / \mathrm{l}$ formaldehyde in saline $(0.9 \mathrm{~g} / \mathrm{l} \mathrm{NaCl})$ and the mixture stored at room temperature prior to manual counting. An outflow sub-sample $(10 \mathrm{ml})$ was collected hourly between 0800 and $1600 \mathrm{~h}$ on day 9 , the $\mathrm{pH}$ measured, and the sample mixed with $1 \mathrm{ml}$ of $\mathrm{HCl}(2 \mathrm{~mol} / \mathrm{l})$ and stored at $-20^{\circ} \mathrm{C}$ prior to subsequent volatile fatty acid (VFA) and ammonium-nitrogen analysis. At $1200 \mathrm{~h}$ on day $9,5.98 \mathrm{mg}$ of ${ }^{15} \mathrm{~N}\left(98 \%\right.$ enriched $\mathrm{SO}_{4}\left({ }^{15} \mathrm{NH}_{4}\right)_{2}$ : Sigma Chemical, Poole, UK) was added to each vessel to instantaneously label the ammonia- $\mathrm{N}$ pool and a solution of $\mathrm{SO}_{4}\left({ }^{15} \mathrm{NH}_{4}\right)_{2}$ added to the artificial saliva to replace the ammonium sulphate and result in an infusion rate of $2.93 \mathrm{mg}{ }^{15} \mathrm{~N}$ per day per vessel. During days 9 to 14 of each period the total overflow was bulked on a daily basis and stored at $-20^{\circ} \mathrm{C}$ prior to freeze drying, and on days 12 to 14 a subsample was taken for ${ }^{15} \mathrm{~N}$ analysis. On day 14 , final vessel contents were homogenised in a blender at a low speed for 1 min prior to isolation of a bacterial pellet as described by Carro and Miller (1999).

\section{Chemical analysis}

Feed, faecal and freeze dried vessel effluent outflow samples were analysed as described previously (Jackson et al., 2004) whilst feed and faecal samples were also analysed for acid insoluble ash (Van Keulen and Young, 1977). Particle size distribution of the four total mixed rations were measured using a Penn State Separator fitted with three sieves with screen sizes of 19.0, 8.0 and $1.18 \mathrm{~mm}$ (Kononoff et al., 2003) and the content of physically effective fibre (peNDF) calculated as the product of the proportion of DM above $1.18 \mathrm{~mm}$ and the neutraldetergent fibre (NDF) content of the diet (Mertens, 1997). Milk samples were analysed for fat, protein and lactose using a Lactoscope FTIR spectrophotometer (Delta Instruments B.V., 
Drachten, Holland). Blood samples were analysed for urea (Randox Laboratories kit catalogue no. UR 221), albumin (Randox Laboratories kit catalogue no. AB 361), glucose (Randox Laboratories kit catalogue no. GL 1611), $\beta$-hydroxybutyrate (BHB; Randox laboratories, kit catalogue no. RB 1008), and non-esterified fatty acids (NEFA; Randox Laboratories kit catalogue no. FA 115) using a Cobas Miras Plus autoanalyser (ABX Diagnostics, Bedfordshire, UK). Plasma insulin concentrations were determined using a ${ }^{125}$-labelled insulin double-antibody radio-immunoassay as described by Richardson et al. (2003). The sensitivity of the assay at ED85 was $2.36 \mu \mathrm{IU}$ per $\mathrm{ml}$ and the intra-assay coefficients of variation for low and high-quality controls were 5.9 and $10.4 \%$, respectively.

The continuous culture effluent outflow samples for VFA analysis were centrifuged at $25000 \mathrm{~g}$ for $20 \mathrm{~min}$, the supernatant decanted, filtered through cellulose filter paper (Whatman, cellulose nitrate $0.2 \mu \mathrm{m}$ ) and the residue discarded. The filtrate was analysed for VFA by gas-liquid chromatography as described by Witt et al. (1999) using a DB-FFAP capillary column of $30 \mathrm{~m}$ length and $0.25 \mathrm{~mm}$ internal diameter (J \& W Scientific, Folsom, California, USA) and phenol as an internal standard. The number of protozoa per $\mathrm{ml}$ was determined by mixing $1 \mathrm{ml}$ of preserved fluid with $4 \mathrm{ml}$ of $0.2 \mathrm{~mol} / \mathrm{l}$ iodine solution and counted as described by Chikunya et al. (2004). Freezedried effluent overflow samples were treated to remove excess ${ }^{15} \mathrm{~N}$-labelled ammonia $\left({ }^{15} \mathrm{NH}_{3}-\mathrm{N}\right)$ as described by Firkins et al. (1992) and outflow and microbial pellets analysed for ${ }^{15} \mathrm{~N}$ on an ANCA/SL 20/20 continuous flow isotope ratio mass spectrometer (IRMS; Europa Scientific Ltd, Crewe, UK) at the Institute of Grassland and Environmental Research, Aberystwyth, UK.

\section{Statistical analysis}

Milk yield parameters, intake, live weight, condition score and blood parameters were evaluated by analysis of variance with the treatment degrees of freedom split into main effects of dietary treatment (Treat), linear (Lin) and quadratic responses (Quad) to rate of inclusion of pWCW. Milk and component yield ( $\mathrm{kg} /$ day) in the week prior to blocking were used, when appropriate, as a co-variate. The in vitro measurements were analysed as a Latin-square design with main effects of vessels, periods and treatment, which was further split into main effects of dietary treatment (Treat), linear (Lin) and quadratic responses (Quad) to rate of inclusion of pWCW. All statistical analysis was conducted using Genstat 6 (VSN International Ltd., Oxford, UK).

\section{Results}

Forage analysis and animal performance

The pWCW had a higher DM, pH, crude protein and starch content than the grass silage (Table 1). By contrast the grass silage had a higher ash content, whilst fibre levels were similar in both forages. The proportion of feed particles greater than $19.0 \mathrm{~mm}$ decreased and that below $8.0 \mathrm{~mm}$ increased linearly with pWCW inclusion rate, but the physically effective fibre was not affected by treatment $(P>0.05$; Table 2). There was no difference $(P>0.05)$ in the DM intake of concentrates between cows fed any of the treatments, which averaged $9.7 \mathrm{~kg}$ DM per day. By contrast, there was a linear effect $(P<0.001)$ of treatment on total forage DM intake, which increased from $9.99 \mathrm{~kg} D M$ per day in cows fed grass silage alone (W-0) to $14.63 \mathrm{~kg}$ DM per day in cows fed 0.75 pWCW (W-75). A similar pattern in total DM intake was observed $(P<0.001)$.

Daily milk yield was $3.6 \mathrm{~kg} /$ day higher in cows fed W-25 compared with those fed grass silage alone (W-0; $P<0.05)$, but there was no difference $(P>0.05)$ between cows fed W-25, W-50 or W-75, or between W-0, $\mathrm{U}-50$ or W-75, although there was a trend $(P=0.09)$ for a quadratic relationship between milk yield and pWCW inclusion rate (Table 3). Milk fat, protein and lactose concentrations were similar between treatments although there was a trend $(P=0.10)$ for milk protein content to increase with the level of inclusion of pWCW. Milk protein yield was $0.11 \mathrm{~kg} /$ day higher $(P<0.05)$ in cows fed $W-25$ compared with $\mathrm{W}-0$, although there was no difference $(P>0.05)$ between cows fed W- $0, \mathrm{~W}-50$ or $\mathrm{W}-75$, and $\mathrm{W}-$ $25, \mathrm{~W}-50$ or $\mathrm{W}-75$. When milk yield was corrected to the same energy content there was no difference $(P>0.05)$

Table 1 Chemical composition ${ }^{\dagger}$ ( $g / \mathrm{kg}$ dry matter (DM)) of grass silage, processed, urea-treated whole-crop wheat (WCW) and concentrate fed to dairy cows

Grass silage Processed WCW Concentrate

\begin{tabular}{lccc}
\hline $\mathrm{DM}(\mathrm{g} / \mathrm{kg})$ & 323 & 836 & 893 \\
Crude protein & 141 & 158 & 239 \\
Ash & 83 & 38 & 95.1 \\
Ammonia-N (g/kg total $\mathrm{N})$ & 32 & 157 & $\mathrm{nd}$ \\
$\mathrm{pH}$ & 4.0 & 8.4 & $\mathrm{nd}$ \\
$\mathrm{DOMD}^{\ddagger}(\mathrm{g} / \mathrm{kg} \mathrm{DM})$ & 688 & 759 & 798 \\
$\mathrm{ME}^{\ddagger}(\mathrm{MJ} / \mathrm{kg} \mathrm{DM})$ & 10.9 & $\mathrm{nd}$ & 13.7 \\
Sugars & 47 & 6.2 & 14.0 \\
$\mathrm{NDF}^{\ddagger}$ & 515 & 505 & 290 \\
$\mathrm{ADF}^{\ddagger}$ & 334 & 211 & 163 \\
Oil & 32 & 23 & 99.4 \\
Starch & $\mathrm{nd}$ & 340 & 161 \\
Ethanol & 11.5 & $\mathrm{nd}$ & $\mathrm{nd}$ \\
Fermentation acids & & & \\
$\quad$ Lactic acid & 119 & nd & nd \\
Acetic acid & 52 & nd & nd \\
Propionic acid & 4.5 & nd & nd \\
Butyric acid & $<0.1$ & nd & nd \\
Iso-valeric acid & $<0.1$ & nd & nd \\
$n$-valeric acid & $<0.1$ & nd & nd \\
\hline \hline
\end{tabular}

${ }^{\dagger} n=$ mean of four replicates per feed.

${ }^{\ddagger}$ Abbreviations are: DOMD = digestible organic matter in the dry matter; $\mathrm{ME}=$ metabolisable energy; $\mathrm{NDF}=$ neutral-detergent fibre; $\mathrm{ADF}=$ aciddetergent fibre.

$\mathrm{nd}=$ not determined. 
Table 2 Mean diet particle size distribution (g/kg dry matter (DM)) and mean intake ( $k g$ DM per day) of concentrates and forage by cows fed diets in which grass silage was substituted for 0 (W-0), 0.25 (W-25), 0.5 (W-50) or 0.75 (W-75) of processed, urea-treated whole-crop wheat (pWCW) on a DM basis

\begin{tabular}{|c|c|c|c|c|c|c|c|c|}
\hline & \multicolumn{4}{|c|}{ Diet } & \multirow[b]{2}{*}{ s.e.d. } & \multicolumn{3}{|c|}{ Significance $^{\dagger}$} \\
\hline & W-0 & W-25 & W-50 & W-75 & & Treat & Lin & Quad \\
\hline \multicolumn{9}{|l|}{ Proportion of diet $^{\ddagger}$} \\
\hline$>19.0 \mathrm{~mm}$ & $362^{\mathrm{b}}$ & $332^{\mathrm{b}}$ & $213^{\mathrm{a}}$ & $161^{\mathrm{a}}$ & 39.8 & $<0.001$ & $<0.001$ & 0.685 \\
\hline $19.0-8.0 \mathrm{~mm}$ & 424 & 430 & 397 & 381 & 25.0 & 0.219 & 0.060 & 0.567 \\
\hline $8.0-1.18 \mathrm{~mm}$ & $180^{\mathrm{a}}$ & $210^{\mathrm{a}}$ & $334^{b}$ & $400^{c}$ & 27.3 & $<0.001$ & $<0.001$ & 0.368 \\
\hline$<1.18 \mathrm{~mm}$ & $34^{\mathrm{ab}}$ & $28^{\mathrm{a}}$ & $56^{b c}$ & $58^{\mathrm{c}}$ & 10.5 & 0.022 & 0.009 & 0.594 \\
\hline Mean particle size $\mathrm{mm}$ & $12.6^{\mathrm{b}}$ & $12.1^{\mathrm{b}}$ & $8.6^{\mathrm{a}}$ & $7.5^{\mathrm{a}}$ & 0.98 & $<0.001$ & $<0.001$ & 0.648 \\
\hline PeNDF $(g / k g ~ D M)^{\S}$ & 391 & 403 & 396 & 397 & 4.3 & 0.114 & 0.497 & 0.118 \\
\hline \multicolumn{9}{|l|}{ Intake } \\
\hline Dairy concentrates & 6.15 & 6.14 & 6.11 & 6.12 & 0.063 & 0.900 & 0.518 & 0.795 \\
\hline Straights & 3.51 & 3.57 & 3.66 & 3.68 & 0.229 & 0.876 & 0.428 & 0.894 \\
\hline Total concentrates & 9.67 & 9.71 & 9.73 & 9.80 & 0.247 & 0.961 & 0.605 & 0.952 \\
\hline Grass silage & $9.99^{c}$ & $9.12^{\mathrm{c}}$ & $6.98^{\mathrm{b}}$ & $3.96^{\mathrm{a}}$ & 0.596 & $<0.001$ & $<0.001$ & 0.007 \\
\hline pWCW & $0.00^{\mathrm{a}}$ & $3.13^{\mathrm{b}}$ & $6.64^{c}$ & $10.66^{\mathrm{d}}$ & 0.372 & $<0.001$ & $<0.001$ & 0.027 \\
\hline Total forage & $9.99^{a}$ & $12.25^{b}$ & $13.58^{\mathrm{bc}}$ & $14.63^{\mathrm{c}}$ & 0.777 & $<0.001$ & $<0.001$ & 0.277 \\
\hline Total DM intake & $19.65^{a}$ & $21.97^{b}$ & $23.31^{b c}$ & $24.43^{c}$ & 1.015 & $<0.001$ & $<0.001$ & 0.414 \\
\hline
\end{tabular}

a,b,c,d Within a row, means without a common superscript letter differ $(P<0.05)$.

${ }^{\dagger}$ Treatment (Treat), linear (Lin) and quadratic responses (Quad) to rate of inclusion of pWCW.

${ }^{\ddagger}$ Total mixed ration only, excludes out of parlour concentrates, $n=5$.

${ }^{\S}$ Calculated as the product of the proportion of DM above $1.18 \mathrm{~mm}$ and the neutral-detergent fibre content.

between treatments. There was also no effect $(P>0.05)$ of treatment on mean locomotion score, live-weight change $(\mathrm{kg} / \mathrm{day})$ or body condition score, but during weeks 11 to 14 inclusive there was an effect $(P<0.05)$ of pWCW inclusion rate on body condition score (Figure 1).

By week 13 of the experiment there was a linear increase $(P<0.001$; Figure 2$)$ in plasma insulin concentrations with pWCW inclusion rate, although there was no effect $(P>0.05)$ of treatment on mean levels (Table 4). By contrast, there was a linear effect $(P<0.001)$ of treatment on mean plasma urea levels, which increased with pWCW inclusion rate. There was a quadratic effect $(P=0.047)$ of level of inclusion of pWCW on plasma albumin levels, being highest in cows fed W-50. Similarly, there was a trend towards a quadratic response $(P=0.07)$ in plasma BHB levels, which were highest in cows fed W-50. There was no effect $(P>0.05)$ of treatment on plasma NEFA levels, which averaged $0.126 \mathrm{mmol} / \mathrm{l}$.

Table 3 Mean milk performance, live weight, condition score and locomotion score of cows fed diets in which grass silage was substituted for 0 (W-0), 0.25 (W-25), 0.5 (W-50) or 0.75 (W-75) of processed, urea-treated whole-crop wheat (pWCW) on a dry-matter basis

\begin{tabular}{|c|c|c|c|c|c|c|c|c|}
\hline & \multicolumn{4}{|c|}{ Diet } & \multirow[b]{2}{*}{ s.e.d. } & \multicolumn{3}{|c|}{ Significance $^{\dagger}$} \\
\hline & W-0 & W-25 & W-50 & W-75 & & Treat & Lin & Quad \\
\hline Milk yield (kg/day) & $34.2^{\mathrm{a}}$ & $37.8^{\mathrm{b}}$ & $35.2^{\mathrm{ab}}$ & $35.8^{\mathrm{ab}}$ & 1.22 & 0.043 & 0.569 & 0.092 \\
\hline \multicolumn{8}{|l|}{ Energy-corrected milk } & 0.070 \\
\hline Fat $(\mathrm{g} / \mathrm{kg})$ & 39.2 & 38.0 & 39.9 & 35.6 & 2.48 & 0.342 & 0.253 & 0.392 \\
\hline Protein (g/kg) & 30.6 & 30.9 & 32.1 & 31.7 & 0.88 & 0.293 & 0.103 & 0.598 \\
\hline Lactose $(\mathrm{g} / \mathrm{kg})$ & 46.6 & 46.1 & 46.2 & 46.6 & 0.54 & 0.799 & 0.779 & 0.345 \\
\hline Fat yield (kg/day) & 1.37 & 1.41 & 1.37 & 1.26 & 0.090 & 0.429 & 0.218 & 0.270 \\
\hline Protein yield (kg/day) & $1.06^{\mathrm{a}}$ & $1.17^{b}$ & $1.11^{\mathrm{ab}}$ & $1.12^{\mathrm{ab}}$ & 0.039 & 0.048 & 0.135 & 0.199 \\
\hline Lactose yield (kg/day) & 1.59 & 1.74 & 1.63 & 1.67 & 0.070 & 0.167 & 0.559 & 0.257 \\
\hline \multicolumn{9}{|l|}{ Live-weight change } \\
\hline (kg/day) & 0.08 & 0.13 & 0.21 & 0.36 & 0.151 & 0.292 & 0.067 & 0.614 \\
\hline Body condition score & 2.33 & 2.31 & 2.43 & 2.48 & 0.117 & 0.430 & 0.137 & 0.696 \\
\hline Locomotion score & 2.36 & 2.32 & 2.28 & 2.42 & 0.279 & 0.965 & 0.894 & 0.655 \\
\hline
\end{tabular}

\footnotetext{
a,b Within a row, means without a common superscript letter differ $(P<0.05)$.

${ }^{\dagger}$ Treatment (Treat), linear (Lin) and quadratic responses (Quad) to rate of inclusion of pWCW.

${ }^{\ddagger}$ Corrected to $3.1 \mathrm{MJ}$ net energy per kg according to AFRC (1995).
} 


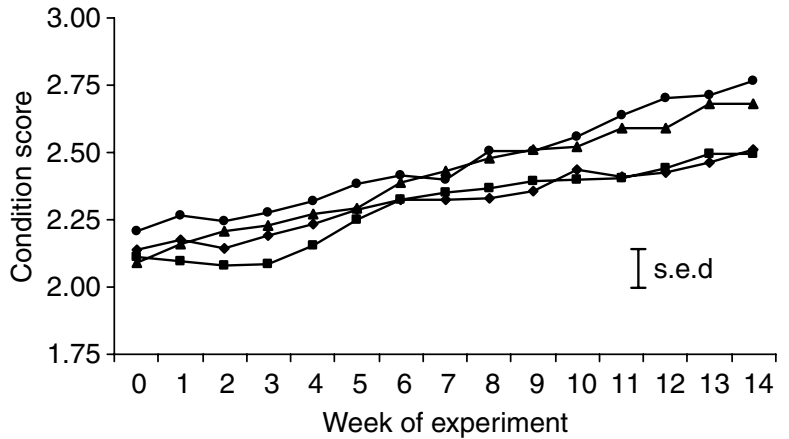

Figure 1 Effect of rate of inclusion of processed, urea-treated wholecrop wheat on the condition score of dairy cows fed diets in which grass silage was substituted for $0(\mathrm{~W}-0 ; \boldsymbol{*}) 0.25$ (W-25; $\mathbf{\square}), 0.5(\mathrm{~W}-50 ; \boldsymbol{\Delta})$ or $0.75(\mathrm{~W}-75 ; 0)$ of processed, urea-treated whole-crop wheat on a drymatter basis.

\section{Apparent digestibility}

Organic matter (OM) intake and faecal output increased linearly with rate of inclusion of pWCW $(P=0.08$ and $<0.001$ respectively), whilst digestibility $(\mathrm{kg} / \mathrm{kg})$ decreased $(P<0.001$; Table 5). By contrast, intake of digestible OM $(\mathrm{kg} /$ day) was similar between treatments, averaging $15.8 \mathrm{~kg} /$ day. Similar to OM, faecal output of NDF increased linearly with rate of inclusion of pWCW $(P<0.001)$, whilst digestibility decreased, with the intake of digestible fibre being similar across treatments, averaging $5.92 \mathrm{~kg} /$ day. Starch intake increased linearly $(P<0.001)$ with rate of inclusion of pWCW but digestibility was similar among treatments at approximately $0.96 \mathrm{~kg} / \mathrm{kg}$ resulting in the intake of digestible starch increasing linearly $(P<0.001)$.

\section{In vitro digestibility and metabolism}

There was no effect of treatment on mean vessel $\mathrm{pH}$, although values tended $(P=0.06)$ to decrease with rate of inclusion of pWCW, whilst vessel ammonia concentration increased linearly $(P<0.05$; Table 6$)$. There was no effect

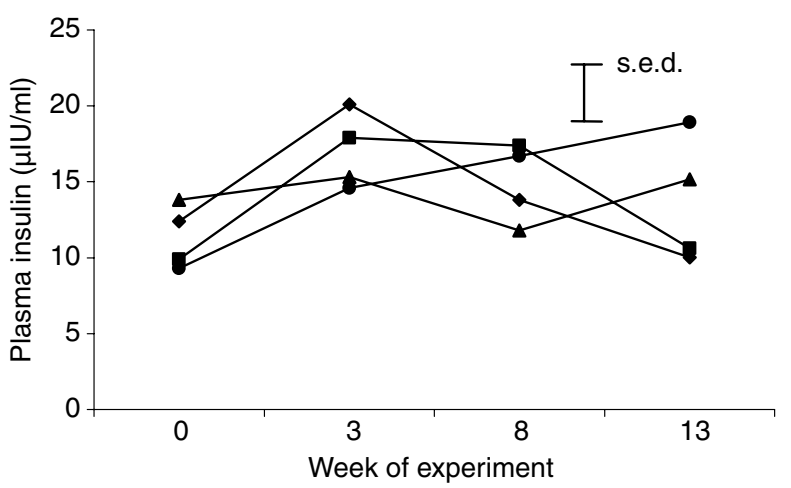

Figure 2 Effect of rate of inclusion of processed, urea-treated wholecrop wheat on plasma insulin concentrations ( $\mu / U$ per $\mathrm{ml}$ ) in dairy cows fed diets in which grass silage was substituted for $0(\mathrm{~W}-0$; $\diamond) 0.25$ $(\mathrm{W}-25 ; \boldsymbol{\square}), 0.5(\mathrm{~W}-50 ; \boldsymbol{\Lambda})$ or $0.75(\mathrm{~W}-75 ; \boldsymbol{\bullet})$ of processed, urea-treated whole-crop wheat on a dry-matter basis. of treatment on mean total VFA concentration. Similarly, there was no effect of treatment $(P>0.05)$ on the proportion of acetate, but butyrate levels increased $(P<0.05)$ and propionate levels decreased $(P<0.001)$ linearly with rate of inclusion of pWCW; as a consequence, the acetate to propionate ratio increased linearly $(P<0.001)$. The number of protozoa per $\mathrm{ml}$ of outflow were similar between treatments on day $1(P>0.05$; mean of $3.0 \times 10^{4} / \mathrm{ml}$ ) but by day 13 numbers had decreased substantially (mean of $5.8 \times 10^{3} / \mathrm{ml}$ ) and there was a linear increase $(P<0.05)$ in numbers with pWCW inclusion rate.

The intake of OM and NDF was similar across treatments and there was no effect of treatment on OM or NDF digestibility $(\mathrm{g} / \mathrm{g})$, which averaged 0.45 and 0.70 respectively, whilst the content of digestible starch ( $g /$ day) increased with pWCW inclusion rate (Table 7). There was no effect of treatment on microbial $\mathrm{N}$ flow (mean value of $0.36 \mathrm{~g} /$ day) or microbial efficiency when expressed as either $\mathrm{g} \mathrm{N}$ per $\mathrm{kg}$ organic matter apparently degraded or truly degraded (mean values of 28.8 and 20.8 respectively).

\section{Discussion}

Intake and performance

The DM content of the WCW used in the current study $(836 \mathrm{~g} / \mathrm{kg})$ was comparable to the processed and unprocessed WCW used in the studies of Sinclair et al. (2005) and Sutton et al. (1998) but higher than that used by Jackson et al. (2004) or Sutton et al. (2001). The optimal DM of pWCW has been shown to be approximately $700 \mathrm{~g} / \mathrm{kg}$, although forages with DM contents above this value have only marginally reduced performance (Bond et al., 2004). In the current study there was a large and significant linear increase in forage DM intake with inclusion rate of pWCW. An increase in forage DM intake when grass silage is replaced with WCW in dairy cows is well established. For example, Hameleers (1998) reported a 0.23 increase in forage DM intake when urea-treated WCW replaced 0.4 of the grass silage, whilst Murphy et al. (2004) reported a 0.38 increase when processed, urea-treated WCW replaced 0.67 of grass silage. By contrast, the effects of rate of inclusion WCW on intake are less apparent; Phipps et al. (1992) and Abdalla et al. (1999) reported a modest increase in forage DM intake with inclusion rate of unprocessed WCW, whilst Sutton et al. (1997) and Hill and Leaver (1991) reported little effect. In general, feeding more rapidly digested starch sources such as wheat can cause a depression in ruminal $\mathrm{pH}$ and may lead to a reduction in DM intake (Grant, 1994). In the current study, despite starch intake increasing from approximately $1 \mathrm{~kg} /$ day on W-0 to $4.6 \mathrm{~kg} /$ day on $\mathrm{W}-75$, forage DM intake increased, although the highest level of starch intake recorded here was substantially lower than that reported in other studies (Overton et al., 1995; Yang et al., 2001).

Despite the large effect of pWCW inclusion on intake, milk yield was highest when it replaced 0.25 of the grass 
Table 4 Mean (weeks 3, 8 and 13) plasma concentrations of insulin, urea, albumin, glucose, $\beta$-hydroxy-butyrate (BHB, non-esterified fatty acids (NEFA) for cows fed diets in which grass silage was substituted for 0 (W-0), 0.25 (W-25), 0.5 (W-50) or 0.75 (W-75) of processed, urea-treated whole-crop wheat ( $p W C W$ ) on a dry-matter basis

\begin{tabular}{|c|c|c|c|c|c|c|c|c|}
\hline & \multicolumn{4}{|c|}{ Diet } & \multirow[b]{2}{*}{ s.e.d. } & \multicolumn{3}{|c|}{ Significance $^{\dagger}$} \\
\hline & W-0 & W-25 & W-50 & W-75 & & Treat & Lin & Quad \\
\hline Insulin ( $\mu$ IU per ml) & 14.6 & 15.3 & 15.9 & 16.1 & 3.55 & 0.974 & 0.655 & 0.919 \\
\hline Urea $(\mathrm{mmol} / \mathrm{l})$ & $4.46^{\mathrm{a}}$ & $5.31^{\mathrm{b}}$ & $5.59^{b}$ & $6.04^{b}$ & 0.385 & 0.008 & $<0.001$ & 0.466 \\
\hline Albumin $(\mathrm{g} / \mathrm{l})$ & 35.5 & 35.7 & 36.2 & 34.1 & 0.714 & 0.070 & 0.13 & 0.047 \\
\hline Glucose (mmol/l) & 3.56 & 3.35 & 3.51 & 3.43 & 0.123 & 0.404 & 0.575 & 0.494 \\
\hline $\mathrm{BHB}(\mathrm{mmol} / \mathrm{l})$ & 0.66 & 0.65 & 0.81 & 0.58 & 0.0791 & 0.062 & 0.767 & 0.071 \\
\hline NEFA (mmol/l) & 0.138 & 0.148 & 0.115 & 0.104 & 0.0296 & 0.441 & 0.168 & 0.622 \\
\hline
\end{tabular}

a,b Within a row, means without a common superscript letter differ $(P<0.05)$.

${ }^{\dagger}$ Treatment (Treat), linear (Lin) and quadratic responses (Quad) to rate of inclusion of pWCW.

silage, but not at the higher rates that have been used in most other studies (Jackson et al., 2004; Murphy et al., 2004; Sinclair et al., 2005). The effects of processed or unprocessed WCW on dairy cow performance have been inconsistent; in most studies there has either been no significant effect or a trend towards an increase in milk yield (Phipps et al., 1995; Sutton et al., 1998). By contrast, milk yield was significantly higher when WCW contributed 0.44 of the forage DM in the study of Hill and Leaver (1991) and was increased in some but not all studies that have fed pWCW (Murphy et al., 2004). Part of this variation may be explained by the quality of the reference grass silage used, with metabolisable energy (ME) values ranging from $10.0 \mathrm{MJ} / \mathrm{kg} \mathrm{DM}$ in the study of Hill and Leaver (1991) to $12.0 \mathrm{MJ} / \mathrm{kg}$ DM reported by Sutton et al. (1998). The lack of a significant increase in milk performance at higher pWCW inclusion rates in the current study may be attributed to a repartioning of dietary energy towards body tissue; body condition score increased with rate of pWCW inclusion, such that by week 11 of treatment the difference was significant. It is well established that increasing dietary starch intake is associated with a partioning of nutrients away from milk fat towards body condition, which may reflect a greater absorption of glucogenic rather than lipogenic precursors (Reynolds et al., 1997). This observation is supported by the plasma insulin levels which increased with pWCW inclusion rate during week 13 . Increasing the inclusion rate of coarse ground cereal grains has also been shown to increase the flow of undigested starch to the small intestine (Beauchemin et al., 2001), and may in theory improve the efficiency of energy utilisation as starch digestion in the small intestine provides more energy than starch digested in the rumen (Reynolds et al., 1997). This is unlikely to have had a major impact in the current study as approximately $0.81 \mathrm{~kg} / \mathrm{kg}$ of the starch in pWCW has been reported to be released within the rumen (Bond,

Table 5 Intake, faecal output, digestible ( $\mathrm{kg} /$ day) and apparent digestibility $(\mathrm{kg} / \mathrm{kg})$ of organic matter, neutral-detergent fibre and starch in cows fed diets in which grass silage was substituted for $0(W-0), 0.25$ (W-25), 0.5 (W-50) or 0.75 (W-75) of processed, urea-treated whole-crop wheat (pWCW) on a dry-matter basis

\begin{tabular}{|c|c|c|c|c|c|c|c|c|}
\hline & \multicolumn{4}{|c|}{ Diet } & \multirow[b]{2}{*}{ s.e.d. } & \multicolumn{3}{|c|}{ Significance $^{\dagger}$} \\
\hline & W-0 & W- 25 & W-50 & W-75 & & Treat & Lin & Quad \\
\hline \multicolumn{9}{|l|}{ Organic matter } \\
\hline Intake & 18.5 & 21.4 & 22.3 & 23.6 & 1.81 & 0.080 & 0.016 & 0.545 \\
\hline Faecal output & $4.01^{\mathrm{a}}$ & $5.00^{\mathrm{ab}}$ & $6.20^{b c}$ & $7.20^{c}$ & 0.520 & $<0.001$ & $<0.001$ & 0.993 \\
\hline Digestible & 14.5 & 16.4 & 16.1 & 16.4 & 1.49 & 0.541 & 0.266 & 0.462 \\
\hline Digestibility & $0.786^{\mathrm{b}}$ & $0.765^{\mathrm{b}}$ & $0.722^{\mathrm{a}}$ & $0.695^{\mathrm{a}}$ & 0.016 & $<0.001$ & $<0.001$ & 0.802 \\
\hline \multicolumn{9}{|l|}{ Fibre } \\
\hline Intake & 7.91 & 9.27 & 9.51 & 9.79 & 0.851 & 0.187 & 0.052 & 0.394 \\
\hline Faecal output & $2.25^{\mathrm{a}}$ & $2.80^{\mathrm{ab}}$ & $3.56^{\mathrm{bc}}$ & $4.16^{c}$ & 0.299 & $<0.001$ & $<0.001$ & 0.903 \\
\hline Digestible & 5.66 & 6.46 & 5.95 & 5.63 & 0.712 & 0.634 & 0.794 & 0.289 \\
\hline Digestibility & $0.720^{c}$ & $0.695^{c}$ & $0.626^{b}$ & $0.575^{a}$ & 0.027 & $<0.001$ & $<0.001$ & 0.514 \\
\hline \multicolumn{9}{|l|}{ Starch } \\
\hline Intake & $1.16^{\mathrm{a}}$ & $2.30^{\mathrm{b}}$ & $3.51^{\mathrm{c}}$ & $5.00^{d}$ & 0.206 & $<0.001$ & $<0.001$ & 0.248 \\
\hline Faecal output & $0.03^{\mathrm{a}}$ & $0.07^{\mathrm{ab}}$ & $0.14^{b}$ & $0.27^{c}$ & 0.0374 & $<0.001$ & $<0.001$ & 0.129 \\
\hline Digestible & $1.13^{\mathrm{a}}$ & $2.22^{\mathrm{b}}$ & $3.37^{c}$ & $4.74^{d}$ & 0.198 & $<0.001$ & $<0.001$ & 0.362 \\
\hline Digestibility & 0.971 & 0.968 & 0.959 & 0.947 & 0.009 & 0.101 & 0.020 & 0.479 \\
\hline
\end{tabular}

$\mathrm{a}, \mathrm{b}, \mathrm{c}, \mathrm{d}$ Within a row, means without a common superscript letter differ $(P<0.05)$.

${ }^{\dagger}$ Treatment (Treat), linear (Lin) and quadratic responses (Quad) to rate of inclusion of pWCW. 
Sinclair, Bond, Huntington and Readman

Table 6 Mean pH, ammonia-nitrogen concentration, volatile fatty acid (VFA) proportion and concentration and protozoa numbers for in vitro vessels given diets in which grass silage was substituted for $0(\mathrm{~W}-0), 0.25(\mathrm{~W}-25), 0.5(\mathrm{~W}-50)$ or $0.75(\mathrm{~W}-75)$ of processed, urea-treated wholecrop wheat (pWCW) on a dry-matter basis

\begin{tabular}{|c|c|c|c|c|c|c|c|c|}
\hline & & & & & & & gnificance & \\
\hline & W-0 & W-25 & W-50 & W-75 & s.e.d. & Treat & Lin & Quad \\
\hline $\mathrm{pH}$ & 6.05 & 6.03 & 5.99 & 5.99 & 0.030 & 0.186 & 0.055 & 0.485 \\
\hline Ammonia-N (mg/l) & $114^{\mathrm{a}}$ & $115^{\mathrm{a}}$ & $145^{\mathrm{ab}}$ & $153^{\mathrm{b}}$ & 12.6 & 0.045 & 0.011 & 0.704 \\
\hline VFA (mmol/mmol) & & & & & & & & \\
\hline Acetic & 53.8 & 53.3 & 54.1 & 54.9 & 0.91 & 0.398 & 0.194 & 0.330 \\
\hline Butyric & 16.5 & 18.2 & 19.3 & 20.3 & 1.12 & 0.064 & 0.012 & 0.690 \\
\hline Propionic & $21.4^{c}$ & $20.1^{b c}$ & $18.8^{\mathrm{ab}}$ & $17.6^{\mathrm{a}}$ & 0.66 & 0.006 & $<0.001$ & 0.897 \\
\hline Minor VFA ${ }^{\ddagger}$ & $8.30^{\mathrm{b}}$ & $8.42^{b}$ & $7.82^{\mathrm{b}}$ & $7.12^{\mathrm{a}}$ & 0.28 & 0.013 & 0.003 & 0.083 \\
\hline Total VFA (mmol/l) & 68.2 & 67.2 & 71.3 & 76.4 & 7.29 & 0.617 & 0.261 & 0.575 \\
\hline Acetate to propionate ratio & $2.52^{\mathrm{a}}$ & $2.65^{\mathrm{ab}}$ & $2.89^{b}$ & $3.16^{\mathrm{c}}$ & 0.10 & 0.004 & $<0.001$ & 0.403 \\
\hline Protozoa numbers $\left(10^{3} / \mathrm{ml}\right)$ & & & & & & & & \\
\hline Day 1 & 31.2 & 34.5 & 31.5 & 23.3 & 7.26 & 0.508 & 0.287 & 0.309 \\
\hline Day 13 & 4.48 & 5.21 & 6.25 & 7.34 & 1.071 & 0.137 & 0.029 & 0.818 \\
\hline
\end{tabular}

$\mathrm{a}, \mathrm{b}, \mathrm{c}$ Within a row, means with different superscript letter differ $(P<0.05)$.

${ }^{\dagger}$ Treatment (Treat), linear (Lin) and quadratic responses (Quad) to rate of inclusion of pWCW.

${ }^{\ddagger}$ Minor VFA includes isobutyric, isovaleric, valeric and caproic acids.

2006) and it is predicted that duodenal starch flow for treatments W-25, W-50 and W-75 compared with W-0 would have been increased by only $0.20,0.43$ and $0.68 \mathrm{~kg} /$ day respectively.

There was no effect of treatment on milk fat content or yield, although both were numerically lower in cows fed $\mathrm{W}-75$. This result is somewhat surprising as it is well established that milk fat production decreases as the ratio of starch:fibre in the diet increases (Sutton, 1989), although the physically effective fibre content of the diet, which has been shown to be related to milk fat content (Mertens, 1997), was similar between treatments. The increase in milk protein yield in cows fed W-25 compared with W-0 may be attributed to effects of increasing starch

Table 7 Mean intake, output, digestible ( $\mathrm{g} /$ day), apparent digestibility $(\mathrm{g} / \mathrm{g})$ of organic matter, neutral-detergent fibre, starch and microbial protein synthesis for in vitro vessels given diets in which grass silage was substituted for 0 (W-0), 0.25 (W-25), 0.5 (W-50) or 0.75 (W-75) of processed, urea-treated whole-crop wheat ( $p W C W$ ) on a dry-matter basis

\begin{tabular}{|c|c|c|c|c|c|c|c|c|}
\hline & \multicolumn{4}{|c|}{ Diet } & \multirow[b]{2}{*}{ s.e.d. } & \multicolumn{3}{|c|}{ Significance $^{\dagger}$} \\
\hline & W-0 & $W-25$ & $W-50$ & W-75 & & Treat & Lin & Quad \\
\hline \multicolumn{9}{|l|}{ Organic matter } \\
\hline Intake & 28.2 & 28.4 & 28.6 & 28.79 & & & & \\
\hline Output & 16.1 & 16.0 & 15.4 & 15.3 & 0.79 & 0.664 & 0.270 & 0.955 \\
\hline Digestible & 12.1 & 12.4 & 13.2 & 13.5 & 0.79 & 0.316 & 0.086 & 0.955 \\
\hline Digestibility & 0.43 & 0.44 & 0.46 & 0.47 & 0.027 & 0.452 & 0.143 & 0.947 \\
\hline \multicolumn{9}{|l|}{ Fibre } \\
\hline Intake & 10.9 & 10.6 & 10.4 & 10.1 & & & & \\
\hline Output & 3.51 & 3.24 & 2.58 & 3.10 & 0.615 & 0.532 & 0.370 & 0.392 \\
\hline Digestible & 7.35 & 7.38 & 7.80 & 7.04 & 0.615 & 0.682 & 0.798 & 0.392 \\
\hline Digestibility & 0.68 & 0.70 & 0.75 & 0.69 & 0.058 & 0.615 & 0.574 & 0.385 \\
\hline \multicolumn{9}{|l|}{ Starch } \\
\hline Intake & 0.81 & 2.22 & 3.62 & 5.03 & & & & \\
\hline Output & $0.02^{\mathrm{a}}$ & $0.03^{\mathrm{ab}}$ & $0.03^{b c}$ & $0.04^{c}$ & 0.005 & 0.008 & $<0.001$ & 0.939 \\
\hline Digestible & $0.80^{\mathrm{a}}$ & $2.20^{\mathrm{b}}$ & $3.59^{c}$ & $4.99^{d}$ & 0.005 & $<0.001$ & $<0.001$ & 0.939 \\
\hline Digestibility & $0.98^{\mathrm{a}}$ & $0.99^{\mathrm{b}}$ & $0.99^{b}$ & $0.99^{b}$ & 0.002 & 0.006 & 0.002 & 0.045 \\
\hline \multicolumn{9}{|c|}{ Microbial protein synthesis } \\
\hline Microbial N (g/day) & 0.36 & 0.39 & 0.35 & 0.35 & 0.025 & 0.415 & 0.421 & 0.491 \\
\hline g N per kg OMAD & 28.9 & 31.3 & 27.9 & 27.3 & 4.97 & 0.852 & 0.608 & 0.684 \\
\hline g N per kg OMTD & 20.9 & 21.8 & 20.3 & 20.0 & 2.52 & 0.890 & 0.623 & 0.729 \\
\hline
\end{tabular}

a,b,c Within a row, means with different superscript letter differ $(P<0.05)$.

${ }^{\dagger}$ Treatment (Treat), linear (Lin) and quadratic responses (Quad) to rate of inclusion of pWCW.

${ }^{\ddagger}$ OMAD = organic matter apparently digested; OMTD = organic matter truly digested. 
intake on microbial protein flow at the duodenum, a greater ruminal propionate absorption rate or a higher ME supply (Reynolds et al., 1997). Increased plasma concentrations of insulin have also been shown to be associated with increased milk protein concentrations, providing amino acid supply is adequate (Reynolds et al., 1997). Reasons for the lack of a significant response in milk protein output at higher inclusion rates of pWCW are less clear as both starch intake and plasma insulin levels increased with WCW inclusion rate, although Phipps et al. (1992) also reported the highest milk protein concentration in cows fed 0.25 of the forage as WCW.

\section{Apparent digestibility}

Acid-insoluble ash was used during week 10 of the current experiment as an indirect method of determining whole tract digestibility. By contrast, other studies that have assessed the digestibility of WCW in dairy cows have used a total collection of faeces (Sutton et al., 1997, 1998 and 2001) and employed a change-over design, generally with a 3 or 4 week adaptation period prior to faecal collection. Starch digestion has however, been shown to increase substantially in both the rumen and the whole tract when dairy cows received an adaptation period of 42 days (Matthé et al., 2003). Additionally, acid-insoluble ash has been shown to have little diurnal variation and result in digestibility coefficients comparable with total collection (Sales and Janssens, 2003).

Sutton et al. (1997) reported a linear decrease in the apparent digestibility of DM and OM with inclusion rate of unprocessed, urea-treated WCW, although no consistent effects on fibre digestibility were reported. As a consequence of a greater DM intake with WCW inclusion rate, this resulted in a similar intake of digestible $\mathrm{OM}$ and a poor efficiency of utilisation of WCW (Sutton et al., 1997). In the current study, digestible $\mathrm{OM}$ intake increased by $1.9 \mathrm{~kg} /$ day when pWCW replaced 0.25 of the grass silage, although the difference was not significant. Whole-tract apparent digestibility of starch was also similar among treatments. If it is assumed that the digestibility of starch in the concentrates was the same as that measured in W-0 $(0.97 \mathrm{~kg} / \mathrm{kg})$ and constant across treatments, the digestibility of starch in the pWCW can be calculated as $0.97,0.95$ and 0.94 (s.e.d. 0.155 ) kg/kg for W-25, W-50 and W-75 respectively, and was not significantly different between treatments. These values are similar to the $0.97 \mathrm{~kg} / \mathrm{kg}$ reported by Jackson et al. (2004) for pWCW but substantially higher than other studies that have fed unprocessed WCW to dairy cows (Sutton et al., 1997 and 1998; Jackson et al., 2004).

\section{In vitro digestibility and metabolism}

Sustained periods of ruminal pH below pH 5.8 to 6.0 can reduce ruminal digestion, rumen motility, appetite and cellulolytic bacteria growth and efficiency (Mould and Ørskov, 1983). In the current experiment, there was a trend $(P=0.06)$ for vessel content $\mathrm{pH}$ to decrease with pWCW inclusion rate, although the difference between treatments was small. This small difference could be attributed to the constant rate of buffer infusion to all treatments which may have had an ameliorating effect on vessel $\mathrm{pH}$. Ruminal $\mathrm{pH}$ in vivo is partly mediated by the rate of saliva release which can be affected by factors including particle size, forage to concentrate ratio and moisture content of the feed (Maekawa et al., 2002). However, the increase in saliva output due to increased chewing time may not be as great as often assumed, as an increased eating and ruminating time decreases resting time when significant amounts of saliva can be released (Maekawa et al., 2002).

Protozoa numbers in vitro have been reported to be considerably lower when compared with levels in vivo (Rufener et al., 1963; Abe and Kumeno, 1973), an effect that may be attributed to a requirement for a large dead space to sequester and find food that is not present in continuous culture systems (Williams and Coleman, 1997). In the current study, numbers of protozoa also decreased substantially after introduction to the vessels, but were higher on day 13 in vessels fed 0.75 WCW, a finding consistent with studies that have fed increasing levels of starch in the diet (Chamberlain et al., 1985). There is still no consensus on the value of protozoa to the host animal although their ability to ingest starch and utilize lactic acid may result in a more stable rumen $\mathrm{pH}$, and their presence has been associated with a decrease in the efficiency of bacterial protein synthesis and flow of $\mathrm{N}$ to the duodenum (Williams and Coleman, 1997).

The mean VFA concentration in the current experiment of $71 \mathrm{mmol} / \mathrm{l}$ was similar to that reported in other studies that have used continuous culture systems (Slyter et al., 1964). In general, bacteria that ferment starch produce a higher proportion of propionic acid than those fermenting cellulose or hemicellulose; as a result increased starch intakes are generally associated with a shift in VFA production away from acetate towards propionate (Overton et al., 1995). By contrast, in the current study, the proportion of acetate to propionate increased linearly with pWCW inclusion rate. This finding is, however, consistent with that of Abdalla et al. (1999) who reported an increased proportion of acetate to propionate when unprocessed WCW replaced grass silage in the diet of dairy cows. Under certain conditions, concentrate diets may encourage the development of a large protozoal population which is accompanied by an increase in butyrate rather than propionate (France and Siddons, 1993). In the current study both butyrate concentrations and protozoal numbers increased linearly with pWCW inclusion rate.

Ammonia- $N$ concentrations were highest in vessels receiving $\mathrm{W}-75$, a finding consistent with the greater content of rumen degradable protein due to the addition of urea as a preservative at ensiling. Abdalla et al. (1999) suggested that increased ammonia values in diets containing WCW may also be a consequence of the reduced ruminal digestion of OM with WCW inclusion, although there was no significant effect of treatment on $\mathrm{OM}$ digestibility 
in the current study. The lack of an effect on OM digestibility may have been due to a longer retention time in vitro than in vivo or an effect of the pre-feeding grinding of the diets, both of which may have permitted a greater opportunity for microbial digestion. This is supported by the high digestibility of starch in the current study, which averaged $0.99 \mathrm{~kg} / \mathrm{kg}$. There was also no effect of treatment on microbial protein synthesis ( $\mathrm{g} /$ day) or efficiency. Microbial efficiency has been shown to be negatively correlated with starch digestion in the rumen (Oba and Allen, 2003) whilst McCarthy et al. (1989) attributed the greater microbial N passage to the small intestine in dairy cows fed barley compared with maize starch to a greater supply of degradable OM. Despite starch levels increasing with pWCW inclusion rate in the current study, the quantity of $\mathrm{OM}$ digested in the rumen was comparable among treatments and would be expected to supply a similar amount of energy for microbial growth.

\section{Conclusions}

Forage DM intake increased linearly with rate of inclusion of pWCW, but there was no further improvement in milk yield from inclusion rates above 0.25 of the forage DM, with body condition score increasing instead. Increasing the inclusion rate of pWCW in vitro resulted in a more ketogenic absorption profile and there was no effect on the efficiency of microbial protein synthesis. Despite the lack of an increase in milk yield at inclusion rates of pWCW above 0.25 of the forage DM, there may be economic and management justification for higher inclusion rates.

\section{Acknowledgements}

The authors would like to acknowledge the Milk Development Council for funding this work, Mr P. King and Mr A Wade for technical assistance and Dr K.D. Sinclair, University of Nottingham, for performing the insulin analysis.

\section{References}

Abdalla AL, Sutton JD, Phipps RH and Humphries DJ 1999. Digestion in the rumen of lactating dairy cows given mixtures of urea-treated whole-crop wheat and grass silage. Animal Science 69, 203-212.

Abe $\mathrm{M}$ and Kumeno $\mathrm{F}$ 1973. In vitro simulation of rumen fermentation: apparatus and effects of dilution rate and continuous dialysis on fermentation and protozoal population. Journal of Animal Science 36, 941-948.

Agricultural and Food Research Council 1995. Energy and protein requirements of ruminants. In An advisory manual prepared by the Technical Committee on Responses to Nutrients. CAB International, Wallingford, UK.

Beauchemin KA, Yang WZ and Rode LM 2001. Effects of barley grain processing on the site and extent of digestion of beef feedlot finishing diets. Journal of Animal Science 79, 1925-1936.

Bond AJ 2006 The effect of stage of maturity and inclusion rate of processed whole crop wheat on the metabolism and performance of dairy cows, Thesis, Open University.

Bond AJ, Readman RJ, Huntington JA and Sinclair LA 2004. The effect of stage of maturity and method of preservation of processed whole-crop wheat on the intake and milk production in dairy cows. Proceedings of the British Society of Animal Science, p.46.

Carro MD and Miller EL 1999. Effect of supplementing a fibre basal diet with different nitrogen forms on ruminal fermentation and microbial growth in an in vitro semi-continuous culture system (RUSITEC). British Journal of Nutrition 82, 149-157.

Chamberlain DG, Thomas PC, Wilson W, Newbold CJ and MacDonald JC 1985. The effects of carbohydrate supplements on ruminal concentrations of ammonia in animals given diets of grass silage. Journal of Agricultural Science, Cambridge 104, 331-340.

Chikunya S, Demirel G, Enser M, Wood JD, Wilkinson RG and Sinclair LA 2004. Biohydrogenation of dietary n-3 PUFA and stability of ingested vitamin $E$ in the rumen, and their effects on microbial activity in sheep. British Journal of Nutrition 91, 539-550.

Firkins JL, Weiss WP and Piwonka EJ 1992. Quantification of intra-ruminal recycling of microbial nitrogen using nitrogen-15. Journal of Animal Science 70, 3223-3233.

France J and Siddons RC 1993. Volatile fatty acid production. In Quantitative aspects of ruminant digestion and metabolism (ed. JM Forbes and J France), pp. 107-121, CAB International, Wallingford, UK.

Grant RJ 1994. Influence of corn and sorghum starch on the in vitro kinetics of forage fiber digestion. Journal of Dairy Science 77, 1563-1569.

Hameleers A 1998. The effects of the inclusion of either maize silage, fermented whole crop wheat or urea-treated whole crop wheat in a diet based on a high-quality grass silage on the performance of dairy cows. Grass and Forage Science 53, 157-163.

Hill J and Leaver JD 1991. Replacement of whole crop wheat by grass silage in the diet of dairy cows. Animal Production 52, 606, (abstr.).

Hill J and Leaver JD 1999. Energy and protein supplementation of lactating dairy cows offered urea treated whole-crop wheat as the sole forage. Animal Feed Science and Technology 82, 177-193.

Hoover WH, Knowlton PH, Stern MD and Sniffen CJ 1976. Effects of differential solid-liquid removal rates on fermentation parameters in continuous cultures of rumen contents. Journal of Animal Science 43, 535-542.

Her Majesty's Stationery Office 2000. Guidance on the operation of the Animals (Scientific Procedures) Act 1986. The Stationery Office, London.

Jackson M, Readman R, Huntington JA and Sinclair LA 2004. The effect of processing at harvest and cutting-height of urea-treated whole crop wheat on performance and digestibility in dairy cows. Animal Science 78, 467-476.

Kononoff PJ, Heinrichs AJ and Buckmaster DR 2003. Modification of the Penn State forage and total mixed ration particle separator and the effects of moisture content on its measurements. Journal of Dairy Science 86, 18581863.

Lowman BG, Scott NA and Somerville SH 1976. Condition scoring of cattle. ESCA bulletin no. 6. East of Scotland College of Agriculture, Ayr

Maekawa M, Beauchemin KA and Christensen DA 2002. Effect of concentrate level and feeding management on chewing activities, saliva production, and ruminal pH of lactating dairy cows. Journal of Dairy Science 85, 1165-1175.

Manson FJ and Leaver JD 1988. The influence of concentrate amount on locomotion and clinical lameness in dairy cattle. Animal Production 47, 185-190.

Matthé A, Lebzien P, Hric I and Flachowsky G 2003. Influence of prolonged adaptation periods on starch degradation in the digestive tract of dairy cows. Animal Feed Science and Technology 103, 15-27.

McCarthy RD Jr, Klusmeyer H, Vicini JL and Clark JH 1989. Effects of source of protein and carbohydrate on ruminal fermentation and passage of nutrients to the small intestine of lactating cows. Journal of Dairy Science 72, 20022016.

MCDougall EO 1948. Studies on saliva. I. The composition and output of sheep's saliva. The Biochemical Journal 43, 99-109.

Mertens DR 1997. Creating a system for meeting the fiber requirements of dairy cows. Journal of Dairy Science 80, 1463-1481.

Mould FL and Ørskov ER 1983. Manipulation of rumen fluid $\mathrm{pH}$ and its influence on cellulolysis in sacco, dry matter degradation and the rumen microflora of sheep offered either hay or concentrate. Animal Feed Science and Technology 10, 1-14.

Murphy JJ, Kavanagh S and Fitzgerald JJ 2004. Comparative evaluation of grass silage, fermented whole crop wheat silage, urea-treated processed whole crop wheat silage and maize silage in the diet of early lactation cows. In Proceedings of the 55th Annual Meeting of the EAAP, paper no. 4.4, 95

Oba M and Allen MS 2003. Effects of diet fermentability on efficiency of microbial nitrogen production in lactating dairy cows. Journal of Dairy Science 86, 195-207. 
Owens FN and Goetsch AL 1988. Ruminal fermentation. In The ruminant animal: digestive physiology and nutrition (ed. DC Church), pp. 145-171, Prentice Hall, New Jersey.

Overton TR, Cameron MR, Elliott JP and Clark JH 1995. Ruminal fermentation and passage of nutrients to the duodenum of lactating cows fed mixtures of corn and barley. Journal of Dairy Science 78, 1981-1998.

Phipps RH, Sutton JD and Jones BA 1995. Forage mixtures for dairy cows: the effect on dry-matter intake and milk production of incorporating either fermented or urea-treated whole-crop wheat, brewers' grains, fodder beet or maize silage into diets based on grass silage. Animal Science 61, 491-496.

Phipps RH, Weller RF and Siviter JW 1992. In Whole-crop cereals (ed. BA Stark and JM Wilkinson), pp. 51-57, Chalcombe Publications, Kent, UK.

Reynolds CK, Sutton JD and Beever DE 1997. Effects of feeding starch to dairy cattle on nutrient availability and production. In Recent advances in animal nutrition (ed. PC Garnsworthy and J Wiseman), pp. 105-134, Nottingham University Press, Nottingham, UK.

Richardson JM, Wilkinson RG and Sinclair LA 2003. Synchrony of nutrient supply to the rumen and dietary energy source and their effects on the growth and metabolism of lambs. Journal of Animal Science 81, 1332-1347.

Rufener WH Jr, Nelson WO and Wolin MJ 1963. Maintenance of the rumen microbial population in continuous culture. Applied Microbiology 11, 374.

Sales J and Janssens GPJ 2003. Acid-insoluble ash as a marker in digestibility studies: a review. Journal of Animal and Feed Sciences 12, 383-401.

Sinclair LA, Wilkinson RG and Ferguson DMR 2003. Effects of crop maturity and cutting height on the nutritive value of fermented whole crop wheat and milk production in dairy cows. Livestock Production Science 81, 257-269

Sinclair LA, Jackson MA, Huntington JA and Readman RJ 2005. The effects of processed, urea-treated whole-crop wheat or maize silage and supplementation of whole-crop wheat on the performance of dairy cows. Livestock Production Science 95, 1-10.
Slyter LL, Nelson WO and Wolin MJ 1964. Modifications of a device for maintenance of the rumen microbial population in continuous culture. Applied Microbiology 12, 374-377.

Stern MD, Bach A and Calsamiglia S 1997. Alternative techniques for measuring nutrient digestion in ruminants. Journal of Animal Science 75, 2256-2276.

Sutton JD 1989. Altering milk composition by feeding. Journal of Dairy Science 72, 2801-2814.

Sutton JD, Abdalla AL, Phipps RH, Cammell SB and Humphries DJ 1997. The effect of the replacement of grass silage by increasing proportions of ureatreated whole-crop wheat on food intake and apparent digestibility and milk production by dairy cows. Animal Science 65, 343-351.

Sutton JD, Cammell SB, Beever DE, Humphries DJ and Phipps RH 1998. Energy and nitrogen balance of lactating dairy cows given mixtures of urea-treated whole-crop wheat and grass silage. Animal Science 67, 203-212.

Sutton JD, Phipps RH, Cammell SB and Humphries DJ 2001. Attempts to improve the utilization of urea-treated whole-crop wheat by lactating dairy cows. Animal Science 73, 137-147.

Tottman DR and Broad H 1987. The decimal code for the growth stages of cereals, with illustrations. The Annals of Applied Biology 110, 441-454.

Van Keulen J and Young BA 1977. Evaluation of acid-insoluble ash as a natural marker in ruminant digestibility studies. Journal of Animal Science 44, 282-287.

Williams AG and Coleman GS 1997. The rumen protozoa. In The rumen microbial ecosystem (ed. PN Hobson and CS Stewart), pp. 73-139, Blackie Academic and Professional, London.

Witt MW, Sinclair LA, Wilkinson RG and Buttery PJ 1999. The effects of synchronizing the rate of dietary energy and nitrogen supply to the rumen on the production and metabolism of sheep: food characterization and growth and metabolism of ewe lambs fed ad libitum. Animal Science 69, 223-235.

Yang WZ, Beauchemin KA and Rode LM 2001. Effects of grain processing, forage to concentrate ratio and forage particle size on rumen $\mathrm{pH}$ and digestion by dairy cows. Journal of Dairy Science 84, 2203-2216. 